\title{
THE IMPLEMENTATION AND STUDYING OF "LIFE ACTIVITY SAFETY" AS A BASIS OF MODERN SAFETY CULTURE
}

\author{
Vesselin MADANSKI \\ „Vasil Levski” National Military University, Veliko Tarnovo, Bulgaria \\ madansky@yahoo.com
}

\begin{abstract}
The implementation and studying of "Life Activity Safety" as an academic and scientific discipline will contribute to the formation in the individual and in the public of a world outlook on the values and goals for the safety of their life activity in the new post-industrial era through a complete review of human safety issues at different levels in this currently changed environment. The safety environment that will affect the state of our security will be characterized by numerous and asymmetric factors, high dynamics, indefiniteness, complex and difficult to predict processes, while the advancement of the higher education and of the research and scientific work form the basis for undertaking actions in the outlining and implementation of sector and common national policies for the development of the individual and the society. The overall concept of safety as an activity of people and their societies to study, prevent, diminish, eliminate, and deflect the dangers and threats that could destroy them and deprive them of fundamental values, inflict unacceptable damage and obstruct their progress are the rationale for the structure, subject-matter and content of the suggested discipline aiming at educating high school and university students in the underlying principles of life activity safety.
\end{abstract}

\section{Keywords: Life Activity Safety, education, safety culture}

\section{Introduction}

In the modern world, the questions of ensuring life activity safety of the individual, as well as that of the society as a whole, acquire increased importance.

The scientific foundation is the general theory of safety. The complex of applied theories based on the general theory of safety, on the modern scientific concepts of the numerous aspects of safety and on the systematic approach, form an important scientific field - "System security".

Life activity safety, posing a serious problem for modernity and using many other sciences for solving it, has developed its own terminology, conceptual schemes, theoretical bases, methods of research, partly reflecting significant components of reality, i.e. they comprise components of the general safety study. Life-activity safety is a triple task, which comprises determining the risk, carrying out preventive actions and protection from the residual risk and should be viewed as a new cultural and educational field and a new scientific and educational discipline. Its content comprises the general principles of the hazardous phenomena and the existing methods and means for protection of the individual in all conditions and environments of habitation.

There has arisen the need for developing an inclusive system to guarantee the life activity safety - "theory - practice education", within the framework of which all modules on the to the complex research/study of the given sphere of human activity and it's further development should 
take place. Life activity safety (LAS) as a scientific discipline and a subject matter should be related to studying the principles governing the arising and development of risks and threats and the means for effective protection of the society (the individuals, their groups, humanity) and the environment, under all circumstances of life activity, against them [1].

\section{Implementation of Life-activity safety}

The "Life-activity safety" as a cultural and educational field would be an instrument for moulding a new security culture in the society, oriented, above all, toward avoiding hazards of any kind. The new culture of safety is a main condition for a transition toward sustainable development, ensuring the right to safe life to the future generations. Its creation is connected to the need of spreading a new outlook, which should contribute to a change in the direction of the human civilization - from maximum satisfaction of the constantly growing material needs at the expense of indiscriminate exploitation of the natural resources towards "manageable development" within the limits of the "economic capacities" of the natural biosphere, as the only environment suitable for human habitation. This culture should satisfy the interests of the individual, the society and the state, as well as those of the whole humanity, in a balanced way [4].

The process of shaping a modern safety culture supposes a transition from a more traditional one, based on re-acting, towards a modern culture, based not only on reacting, but also on the methods of prognosis and hazard avoidance.

The objective of the modern safety is the creation of outlook values and personal and social safety and security goals by means of a complex approach toward the issue of individual safety on a personal, professional, national and global scale in the current changed environment.

\section{Studying of Life-activity safety}

The main channel form building a modern safety culture is education.

The study of these problems should take place at all stages of the education and training of the individual, while retaining a continual, tiered and modular character.

The structure of education in life activity safety should comprise three thematic content lines: the individual and the environment, providing for the safety of the individual in the various environments and global security problems [3].

The foundation stone of the cultural and educational field of Life Activity Safety should be the main worldview module, comprising the causes for its appearance, the content and the systematization of the modern complex of security issues and the ways for overcoming them [2].

At the stage of the preschool and primary education, along with this line, at an level accessible for a child, modules on the safe behaviour in everyday life should be included as well.

At the primary and secondary stage of education, it is appropriate to study specialized subject matter, Life activity safety basics and modules on the safety, reflecting the various fields of human activity, within the various subject matters.

On the whole, this complex would represent a general education field where all components are interrelated:

a) the first level (1-4 grade) - student safety;

b) the second level (5-9 grade) - individual safety;

c) в) the second level (10-11 grade) social and state security

The content matter of the discipline "Basics of Life Activity Safety", apart from the viewpoint module at a level appropriate for the respective age, should include the following modules:

- safe behaviour in everyday life;

- survival in extreme situations and conditions;

- healthy lifestyle and first-air basics;

- state institutions for protection of the population in extreme situations; 
- role of the public organizations in ensuring safety;

- obligations of the citizens in defending the country and in non-military crises and missions, and tasks of the armed forced.

At the university stage, all specialties should include the "Life activity safety" subject matter, its content comprises the following modules:

- technology and organization of protection of facilities from a given

- of the natural and social environment from the consequences of a given professional activity.

The subject matter "Life activity safety" should be mandatory general professional subject matter, which combines topics related to the safe interaction of the humans with the habitat (industrial, residential, urban and natural) and the issues of the protection against the negative factors of the accompanying hazardous to extreme conditions. Studying this subject matter leads to creating an idea of the indestructible unity of the efficient professional activity and the individual safety and security requirements. The implementation of these requirements guarantees preservation of the job performance and the health of the individuals and prepares them for actions in extreme situations and conditions. The subject matter should deal with: habitat contemporary state and negative factors, principles of ensuring the safety of interaction of the human species with the habitat, consequences from the action of the extreme factors on the humans and the principles of identifying those factors.

With the post degree education, in line with the policy of lifelong training and learning, it is appropriate to study educational modules, depending on the educational goals and background. They comprise analysis of the recent events and tendencies in providing individual, national and international safety and security.

The following topics can serve as a basis for establishing the Life activity safety" as an educational and professional-training field:

1. Dialectics of the relations within the system "Nature- Individual - Society";

2. Object, subject and subject matter of LAS;

3. Theory on LAS;

4. Goals and principles of ensuring LAS;

5. Theory of risk basics;

6. Possibility estimate of hazardous events in various work-related situations;

7. Factors of destabilisation, characteristics, prevention;

8. Sources of threat, causes for arising, measures to anticipate and remove;

9. Security system concept, principles of design;

10. Classification of the hazardous and extraordinary situations.

In teaching the discipline, the priority fields are: the modern complex of security issues; basics of the safe behaviour in the emergencies and extreme situations, natural or manmade in character, hazardous situations with social significance, basic medical knowledge and healthy way of life. "Life activity safety" in education is a unified, continuous system of pedagogical activity, ensuring a reliable level of individual preparedness in the field of personal, social and national life activity safety, protection of life and safeguarding and improving the health.

The specifics of the life activity safety teaching content can be summed up as follows:

- integratedness (the issues cover many fields of human activity and is an outcome of the interaction of various systems oriented towards the protection of human health and life and protection of the environment;

- the orientation of the teaching process toward education the students in a modern safety culture to minimize the negative impact of the human factor on the personal, social and state safety; 
- in the need to design the structure and categorise the teaching content on the basis of a modules and a complex approach in filling up the content.

\section{Conclusion}

The implementation and studying of "Life Activity Safety" as an academic and scientific discipline will contribute to the formation in the individual and in the public of a world outlook on the values and goals for the safety of their life activity in the new post-industrial era through a complete review of human safety issues at different levels in this currently changed environment.

The overall concept of safety as an activity of people and their societies to study, prevent, diminish, eliminate, and deflect the dangers and threats that could destroy them and deprive them of fundamental values, inflict unacceptable damage and obstruct their progress are the rationale for the structure, subject-matter and content of the suggested discipline aiming at educating high school and university students in the underlying principles of life activity safety.

\section{References}

[1] Власова Л.М., Сапронов В.В., Фрумкина Е.С., Шершнев Л.И., Безопасность жсизнедеятельности. Современный комплекс проблем безопасности. Учебнометодическое пособие для образовательных учреждений. Под ред. Сапронова В. В., Москва, 2009.

[2] Мадански, В., Н. Гаджалов. Безопасността на жизнената дейност като научна и учебна дисииплина. Сборник доклади от годишната университетска научна конференция с международно участие. НВУ „Васил Левски”, 2011, т. 2

[3] Михайлов Л. А., Соломин В. П., Михайлов А. Л. и др., Безопасность жсизнедеятельности. Под ред. Л. А. Михайлова. СПб. : Питер, 2005.

[4] Формирование културы безопасности жизнедеятельности - ГОСТ Р 22.3.ХХ. М., 2012 